\title{
Effects of supplementation of lysophosphatidylcholine (LPC) to lying hens on production performance, fat digestibility, blood lipid profile, and gene expression related to nutrients transport in small intestine
}

\author{
W. Juntanapum, Ch. Bunchasak¹, T. Poeikhampha, Ch. Rakangthong and K. Poungpong \\ Kasetsart University, Faculty of Agriculture, Department of Animal Science \\ Ngam Wong Wan Rd., Lat Yao,Bangkok 10900, Thailand
}

KEY WORDS: Iysophosphatidylcholine, egg production, fat digestibility, gene expression

Received: $\quad 26$ July 2020

Revised: 2 August 2020

Accepted: 4 September 2020
${ }^{1}$ Corresponding author:

e-mail: agrchb@ku.ac.th

\begin{abstract}
This study was conducted to evaluate the effects of lysophosphatidylcholine (LPC) supplementation on egg production, fat digestibility, blood lipid profile and gene expression related to nutrients transport in brown egglaying hens. In total, 384 commercial laying hens were divided into 4 groups (8 replicates, 12 animals each): 1. positive control $(P C), 2$. negative control (reduced energy to $75 \mathrm{ME} \mathrm{kcal} / \mathrm{kg}$; NC), 3. NC-LPC 0.05\%, and 4. NC-LPC $0.1 \%$, accordingly to a completely randomized design. There were no significant effects on productive performance during 33-41 weeks of age. Feed intake and feed conversion ratio (FCR) significantly increased $(P<0.05)$ in the NC group in comparison to the $P C$ group during $42-49$ weeks of age. Supplementation of LPC (at both levels) significantly reduced feed intake and FCR $(P<0.05)$. Consequently, it significantly reduced feed cost per egg weight $(P<0.05)$. In animals supplemented with LPC increased $(P<0.05)$ digestibilities of dietary fat, low-density lipoprotein cholesterol (LDL-C), triglyceride and cholesterol in blood were found. The expression of gene BAT in the epithelial layer of the jejunum significantly increased in the NC group, however it decreased in the NC-LPC $0.1 \%$ group $(P<0.05)$. The expression of CAT-1 gene in the NC-LPC $0.1 \%$ group was higher than that of the PC group $(P<0.05)$. The supplemental LPC (both levels) also significantly increased the expression of the NPC1 gene in comparison to the NC group $(P<0.05)$. So, supplementation of LPC to the diet improved the feed efficiency via the increase of fat digestibility and the uptake of some amino acids or cholesterol to the enterocyte up-regulating the expression of some amino acids and cholesterol transporter genes.
\end{abstract}

\section{Introduction}

Lysophosphatidylcholine (LPC) is produced from the catalytic of soy-lecithin by phospholipase $A_{2}$ activity (Joshi et al., 2006; Liu et al., 2011), so it has a greater hydrophilic properties than regular phospholipids due to the removal of one fatty acid (Joshi et al., 2006; Liu et al., 2011).
LPC may be an effective natural emulsifier, since the critical micelle concentration (CMC) of LPC is $0.02-0.2 \mathrm{mM} / 1$ which is about $20-200$ times less than bile acid $(\mathrm{CMC}=4 \mathrm{mM} / 1)$ and lecithin $(\mathrm{CMC}=0.3-2.0 \mathrm{mM} / \mathrm{l})$ (Langmuir, 2002). Therefore, supplementing LPC seems to increase the digestion, absorption of dietary fat, and productive performance of an animal. Accordingly, Xing et al. (2004), 
Zhang et al. (2011) and Jansen et al. (2015) reported that body weight and fat digestibility of piglet and broiler chicken were improved by LPC supplementation. Conversely, serum cholesterol, triglyceride was decreased (Malapure et al., 2011; Boontiam et al., 2017).

It was evidenced that LPC has an impact on forming spherical micelles in aqueous solution of the gastrointestinal (GI) tract (Vasanthakumari et al., 2011), modifying membranous proteins including ion channels (Maingret et al., 2000), and increasing the number and size of the membranous pores (Baskaran, 2003). Consequently, an increase in the flux rate of macromolecules across the cell membrane (Kelkar and Chattopadhyay, 2007; Lundbaek et al., 2010) was found due to the changing protein structure that alters the hydrophobic interface between the protein and the surrounding bilayer (Lundbaek et al., 2010). Since fat digestion, absorption, synthesis, transportation and accumulation in laying hens are important for egg production, supplementation of LPC may improve fat utilization (solubility, digestion and absorption) and/ or utilization of other nutrients. Therefore, this study was conducted to evaluate the effect of LPC on productive egg performance, fat digestibility, blood lipid content and the expression of genes encoding nutrient transporters in the small intestine of laying hens.

\section{Material and methods}

\section{Animals and management}

In total, 384 Lohmann Brown-Classic laying hens were used in the 16-week experiment (33-49 weeks of age). After the 4-week adaptation period, animals were divided into 4 experimental groups accordingly to a completely randomized design. Each group consisted of 8 replications and 12 hens in each. Under an evaporative cooling system, the hens were kept in wire cages with 4 hens per cage $\left(450 \mathrm{~cm}^{2}\right.$ per hen), and the lighting program was set $16 \mathrm{~h} /$ day. Feed and water were offered ad libitum.

\section{Experimental diets}

Animals were fed four experimental diets: 1. PC (positive control): ME (metabolizable energy) $=2812 \mathrm{kcal} / \mathrm{kg}$, fat $=7.34 \% ; 2$. NC (negative control): $\mathrm{ME}=2737 \mathrm{kcal} / \mathrm{kg}$, fat $=5.76 \%$; 3 . NC-LPC $0.05 \%$ : $\mathrm{ME}=2737 \mathrm{kcal} / \mathrm{kg}$, fat $=5.76 \%, \mathrm{LPC}=0.05 \%$; and 4. NC-LPC 0.1\%: ME $=2737 \mathrm{kcal} / \mathrm{kg}$, fat $=5.76 \%$, LPC $=0.10 \%$ (Table 1$)$.

LPC was sourced from Devenish Nutrition (Belfast, Northern Ireland) and marketed under the trade name Lipidol ${ }^{\circledR}$ (50\% lysophosphatidylcholine along with an inert calcium silicate carrier; Easy Bio, Inc., Seoul, South Korea).
Table 1. Feed ingredients and chemical composition of experimental diets fed to animals

\begin{tabular}{|c|c|c|c|c|}
\hline \multirow[b]{2}{*}{ Indices } & \multicolumn{4}{|l|}{ Group } \\
\hline & $\begin{array}{l}\text { positive } \\
\text { control } \\
\text { (PC) }\end{array}$ & $\begin{array}{l}\text { negative } \\
\text { control } \\
\text { (NC) }\end{array}$ & $\begin{array}{l}\text { NC+LPC } \\
0.05 \%\end{array}$ & $\begin{array}{l}\text { NC+LPC } \\
0.1 \%\end{array}$ \\
\hline Maize & 54.99 & 57.04 & 57.04 & 57.04 \\
\hline Soybean $48 \%$ CP & 27.36 & 26.99 & 26.99 & 26.99 \\
\hline Palm oil & 4.94 & 3.26 & 3.26 & 3.26 \\
\hline DL-Methionine & 0.24 & 0.24 & 0.24 & 0.24 \\
\hline L-lysine $\mathrm{HCl}$ & 0.01 & 0.02 & 0.02 & 0.02 \\
\hline MCP 22\% P & 1.54 & 1.53 & 1.53 & 1.53 \\
\hline Calcium carbonate & 9.72 & 9.72 & 9.72 & 9.72 \\
\hline Salt & 0.30 & 0.30 & 0.30 & 0.30 \\
\hline Sodium bicarbonate & 0.40 & 0.40 & 0.40 & 0.40 \\
\hline Premixes $^{1}$ & 0.50 & 0.50 & 0.50 & 0.50 \\
\hline LPC & 0.00 & 0.00 & 0.05 & 0.10 \\
\hline Total & 100 & 100 & 100.05 & 100.10 \\
\hline Cost/kg, bath & 12.24 & 12.16 & 12.28 & 12.42 \\
\hline ME for poultry, kcal/kg & 2812 & 2737 & 2737 & 2737 \\
\hline Crude protein, \% & 17.00 & 17.00 & 17.00 & 17.00 \\
\hline Methionine, \% & 0.44 & 0.51 & 0.51 & 0.51 \\
\hline Methionine+cystine, \% & 0.8 & 0.8 & 0.8 & 0.8 \\
\hline Lysine, $\%$ & 0.9 & 0.9 & 0.9 & 0.9 \\
\hline Threonine, $\%$ & 0.65 & 0.65 & 0.65 & 0.65 \\
\hline Tryptophan, \% & 0.19 & 0.19 & 0.19 & 0.19 \\
\hline Fibre, $\%$ & 3.68 & 3.73 & 3.73 & 3.73 \\
\hline Fat, \% & 7.34 & 5.76 & 5.76 & 5.76 \\
\hline Calcium, \% & 4.10 & 4.10 & 4.10 & 4.10 \\
\hline Total P, \% & 0.62 & 0.62 & 0.62 & 0.62 \\
\hline Available P, \% & 0.42 & 0.42 & 0.42 & 0.42 \\
\hline $\mathrm{Na}, \%$ & 0.25 & 0.25 & 0.25 & 0.25 \\
\hline
\end{tabular}

LPC - lysophosphatidylcholine, CP - crude protein, MCP - monocalcium phosphate; ${ }^{1}$ contained per $\mathrm{kg}$ of diet, MIU: vit. A 5.0, vit. $D_{3} 1.2 ;$ IU:vit. E4000; $g$ :vit. $K_{3} 0.6, B_{1} 0.8, B_{6} 1.2, B_{12} 0.0025$, nichotinic acid 5.00, pentothenic acid 3.76 , folic acid 0.2 , biotin $0.036, \mathrm{Mn} 24.00$, Zn 20.00, Fe 16.00, Cu 4.00, lodine 0.8, Co 0.08, Se 0.04; and carrier added to $1 \mathrm{~kg}$ premix; ME - metabolizable energy

\section{Egg production}

The productive performance was divided into 2 periods (33-41 and 42-49 weeks of age, respectively). Hens were weighed at the beginning (week 33) and at the end of the study (week 49). The percentage of egg production and egg weight were recorded daily. Feed intake was measured every 14 days and reported cumulatively. From these data, egg weights, egg masses, feed intake, feed conversion ratio (FCR), feed cost per $1 \mathrm{~kg}$ egg (FCE) were cumulatively calculated.

\section{Blood lipid profile}

At the end of the experiment, after $6 \mathrm{~h}$ of feeding withdrawal, blood was randomly collected from the wing vein (one hen from each replication). 
The samples were immediately transferred into nonheparinized vacuum tubes, placed at room temperature for $2 \mathrm{~h}$ for serum separation, and centrifuged $(3000 \mathrm{~g})$ at $4 \mathrm{c}$ for $10 \mathrm{~min}$. The serum was removed into vials and immediately delivered to the laboratory. Consequently, the samples were stored at $-20^{\circ} \mathrm{C}$ until further analysed.

Total cholesterol (TC) and triglyceride (TG) concentrations in the serum were analysed with the Olympus AU400 analyser (E for L Aim Public Company Limited, Tokyo, Japan). High-density lipoprotein cholesterol (HDL-C) and low-density lipoprotein cholesterol (LDL-C) concentrations were evaluated with the ABX Pentra 400 analyser (HORIBA Limited, Bangkok, Thailand).

\section{Fat digestibility}

At 49 weeks of age, the faeces from 4 hens from each replicate (32 hens/group) were randomly collected in order to evaluate the fat digestibility. During the collection period, faeces were cleaned from contaminations of scales and feathers, then immediately stored frozen at $-20^{\circ} \mathrm{C}$. All representative samples were dried in an oven using air-force drying for $72 \mathrm{~h}$ at $60{ }^{\circ} \mathrm{C}$. Analyses of experimental diets and dried excreta were performed using the standard protocols of AOAC International (2000) for measuring digestibility of ether extract (EE) by Soxhlet analysis and dry matter (DM). The analysed values of ingested and excreted nutrients were used to calculate apparent total tract digestibility (Khan et al., 2003): fat digestibility $(\%)=[($ fat intake - fat in faeces $) /$ fat intake] $\times 100$.

\section{RNA isolation and quantitative Real-Time PCR}

One hen per replication (from 6 replications) was randomly selected from each pen. The small intestine (jejunum) was removed, slit open and carefully rinsed in normal saline. Mucosal enterocyte scraping by glass cover slip was used for the isolation of intestinal RNA. The samples were placed in RNAlater ${ }^{\circledR}$ solution (Ambion, Austin, TX, USA) and stored at $4{ }^{\circ} \mathrm{C}$ for $24 \mathrm{~h}$ prior to storage at $-80{ }^{\circ} \mathrm{C}$. Frozen tissue was disrupted in Trizol reagent (Invitrogen) to isolate total RNA. The quality of RNA was assessed using NanoDrop. One microgram of total RNA was reverse-transcribed with SuperScript II (Invitrogen, Carlsbad, CA, USA) to cDNA. Real-Time PCR consisted of total reaction volumes of $10 \mu \mathrm{l}$, containing $2 \mu \mathrm{l}$ SYBR $^{\circledR}$ Green Master Mixes (Applied Biosystems, Foster City, CA, USA), $2 \mu \mathrm{l}$ (500 ng) cDNA, $0.25 \mu \mathrm{l}(10 \mu \mathrm{m})$ forward primer, $0.25 \mu \mathrm{l}(10 \mu \mathrm{m})$ reverse primer and $5.5 \mu \mathrm{l}$ sterile deionized water. Quantitative PCR was performed in triplicate on the CFX Connect Real-Time System (BIO-RAD, Hercules, CA, USA) under the following conditions: an initial activation at $95^{\circ} \mathrm{C}$ for $15 \mathrm{~min}$ and followed by 40 cycles of denaturation at $94{ }^{\circ} \mathrm{C}$ for $30 \mathrm{~s}$, annealing (Table 2) for $20 \mathrm{~s}$ and elongation at $72{ }^{\circ} \mathrm{C}$ for $30 \mathrm{~s}$. Primer sequences for target transcripts were

Table 2. Primer used for real-time PCR

\begin{tabular}{|c|c|c|c|c|c|}
\hline Gene & GenBank ID & $\begin{array}{l}\text { Description or } \\
\text { gene function }\end{array}$ & Primer sequence & $\begin{array}{l}\text { Annealing } \\
\text { temperature, }{ }^{\circ} \mathrm{C}\end{array}$ & Reference \\
\hline SGLT1 & NM_001293240.1 & $\begin{array}{l}\mathrm{Na}^{+} \text {-dependent glucose } \\
\text { and galactose transporter }\end{array}$ & $\begin{array}{l}\text { 5'-CGAGATGCTGTCACTGGAGATC } \\
\text { 3'-ACCAGTACCACAGAGTAAGGATGCT }\end{array}$ & 59 & $\begin{array}{l}\text { Awad et al. } \\
(2014)\end{array}$ \\
\hline GLUT2 & NM_207178.1 & $\begin{array}{l}\mathrm{Na}^{+}-\text {independent glucose, } \\
\text { galactose and fructose transporter }\end{array}$ & $\begin{array}{l}\text { 5'-GAGGAAACTGTGACCCGATGA } \\
\text { 3'-ACTCTCTTTTCACTCGCAGCTTCT }\end{array}$ & 57 & $\begin{array}{l}\text { Awad et al. } \\
(2014)\end{array}$ \\
\hline BAT & NM_001199133.1 & $\begin{array}{l}\mathrm{Na}^{+} \text {-independent cationic and } \\
\text { zwitterionic amino acid transporter }\end{array}$ & $\begin{array}{l}\text { 5'-CAGTAGTGAATTCTCTGAGTGTGAAGCT } \\
\text { 3'-GCAATGATTGCCACAACTACCA }\end{array}$ & 58 & $\begin{array}{l}\text { Gilbert et al. } \\
\text { (2007) }\end{array}$ \\
\hline ASCT1 & XM_001232899.5 & $\begin{array}{l}\mathrm{Na}^{+} \text {-dependent neutral amino acid } \\
\text { transporter }\end{array}$ & $\begin{array}{l}\text { 5'-TTGGCCGGGAAGGAGAAG } \\
\text { 3'-AGACCATAGTTGCCTCATTGAAT }\end{array}$ & 59 & $\begin{array}{l}\text { Su et al. } \\
(2015)\end{array}$ \\
\hline CAT-1 & NM_001145490.1 & $\begin{array}{l}\mathrm{Na}^{+} \text {-independent cationic amino } \\
\text { acid transporter }\end{array}$ & $\begin{array}{l}\text { 5'-CAAGAGGAAAACTCCAGTAATTGCA } \\
\text { 3'-AAGTCGAAGAGGAAGGCCATAA }\end{array}$ & 59 & $\begin{array}{l}\text { Gilbert et al. } \\
\text { (2007) }\end{array}$ \\
\hline$L P L$ & NM_205282.1 & Lipoprotein lipase & $\begin{array}{l}\text { 5'-GACAGCTTGGCACAGTGCAA } \\
\text { 3'-CACCCATGGATCACCACAAA }\end{array}$ & 59 & $\begin{array}{l}\text { Saneyasu } \\
\text { et al. }(2015)\end{array}$ \\
\hline UPC3 & NM_204107.1 & Avian uncoupling protein 3 & $\begin{array}{l}\text { 5'ACTCTGTGAAGCAGCTCTACACC } \\
\text { 3'-ATGTACCGCGTCTTCACCACATC }\end{array}$ & 59 & $\begin{array}{l}\text { Abe et al. } \\
(2006)\end{array}$ \\
\hline FAT/CD36 & NM_001030731.1 & Fatty acid translocase & $\begin{array}{l}\text { 5'-TGCGCTTCTTCTCCTCTGACA } \\
\text { 3'-TCACGGTCTTACTGGTCTGGTAAAC }\end{array}$ & 59 & $\begin{array}{l}\text { Saneyasu } \\
\text { et al.(2015) }\end{array}$ \\
\hline PLA2 & NM_001277914.1 & Phospholipase A2 & $\begin{array}{l}\text { 5'-ATGAGCAGAGCTGGTGCAAA } \\
\text { 3'-GCGGTAGGACACGTTGTAGG }\end{array}$ & 59 & $\begin{array}{l}\text { Karray et al. } \\
(2014)\end{array}$ \\
\hline NPC1 & XM_419162.6 & $\begin{array}{l}\text { Niemann-Pick C1/ intracellular } \\
\text { cholesterol transporter } 1\end{array}$ & $\begin{array}{l}\text { 5'-CATTTTCTGCGGAACGGAGC } \\
\text { 3'-GTGCTGACATCACTCCTGCT }\end{array}$ & 59 & - \\
\hline GAPDH & NM_204305 & $\begin{array}{l}\text { Glyceraldehyde 3-phosphate } \\
\text { dehydrogenase }\end{array}$ & $\begin{array}{l}\text { 5'-CCATCACAGCCACACAGAAGAC } \\
\text { 3'-TGGACGCTGGGATGATGTT }\end{array}$ & 59 & $\begin{array}{l}\text { Awad et al. } \\
(2014)\end{array}$ \\
\hline
\end{tabular}


selected as previous reports or designed with Vector NTI (Thermo Fisher Scientific, Walthom, MA, USA) (Table 2).Relative mRNA expression was analysed by using chicken GAPDH (glyceraldehyde 3-phosphate dehydrogenase) mRNA expression as a reference gene. Therefore, the gene expression rates were quantitated by normalization for transcription rates of the housekeeping gene GAPDH. The deltadelta $\mathrm{Ct}$ equation was utilized to determine the relative fold-change in mRNA abundance (Livak and Schmittgen, 2001).

\section{Statistical analyses}

Data were analysed using two-way analysis of variance (ANOVA) in a completely randomized design. Differences among treatment means were tested for significance by using the Duncan's multiple range tests at 5\% significance level. All other analyses were performed using SAS Version 9.0 (SAS, 2014), SAS Institute, Inc., Cary, NC (USA).

\section{Results and discussion}

Productive performance. Productive performances of the hens are presented in Table 3. There were no significant effects of the experimental diets during 33-41 weeks of age. However, during 42-49 weeks of age, feed intake and energy intake were significantly increased in the NC group, resulting in poor FCR $(P<0.05)$ and high FCE in comparison to the PC group. Feeding NC-LPC $0.05 \%$ and $0.1 \%$ diets significantly improved FCR and reduced FCE of the laying hens were observed $(P<0.05)$.
It was shown that during 33-41 weeks of age, a reduction in the energy content of the diet to $75 \mathrm{kcal}$ has no significant negative effects on the hen productive performance. This may be connected with the fact that hens used their body energy reserves to support the energy requirement for egg production. Nevertheless, a longer period of energy depletion (42-49 weeks of age) negatively affected FCR - increased feed intake compensated energy requirement. Supplementation of LPC significantly decreased feed intake, and significantly improved the FCR in comparison to PC and NC groups. This means that LPC may improve energy utilization in an animal fed a low-energy diet by increasing the fat digestibility or absorption, or other nutrients uptake, as LPC supplementation increases the emulsification of fat or changes the structure of the lipid bilayer of the cell membrane. This is agreement with the results of Beemster et al. (2002), Attia et al. (2009), Han et al. (2010b), Boontiam et al. (2017) and Mandalawi et al. (2015) who observed improved productive performance and feed efficiency contributed to various phospholipid functions (physiological processes of the reproductive system) by supplementing LPC.

Fat digestibility and blood lipids content. Effects of LPC supplementation on fat digestibility and blood lipids content in the laying hens at 49 weeks of age are presented in Table 4. The fat digestibility in animals from the NC group was significantly lower than that from the PC group $(P<0.05)$, while in animals from the NC-LPC 0.05 and $0.1 \%$ groups fat digestibility was clearly increased $(P<0.05)$. However, the supplementation of LPC $(0.05$ and $0.1 \%)$

Table 3. Effect of lysophosphatidylcholine (LPC) supplementation on egg production

\begin{tabular}{|c|c|c|c|c|c|}
\hline Indices & $\begin{array}{l}\text { Positive control } \\
\text { (PC) }\end{array}$ & $\begin{array}{l}\text { Negative control } \\
\text { (NC) }\end{array}$ & $\begin{array}{l}N C+L P C \\
0.05 \%\end{array}$ & $\begin{array}{l}\text { NC+LPC } \\
0.1 \%\end{array}$ & $P$-value \\
\hline \multicolumn{6}{|l|}{ Weeks 33-41 } \\
\hline egg production, \% & $95.12 \pm 1.39$ & $93.37 \pm 3.66$ & $95.01 \pm 3.26$ & $94.15 \pm 3.38$ & $>0.05$ \\
\hline egg weight, $g$ & $65.58 \pm 0.77$ & $66.68 \pm 2.88$ & $67.26 \pm 1.79$ & $67.43 \pm 1.15$ & $>0.05$ \\
\hline egg mass, g/hen/day & $62.46 \pm 1.68$ & $62.50 \pm 2.91$ & $63.79 \pm 3.50$ & $63.28 \pm 2.92$ & $>0.05$ \\
\hline feed intake, g/hen/day & $117 \pm 3.59$ & $124 \pm 5.90$ & $120 \pm 2.06$ & $120 \pm 0.89$ & $>0.05$ \\
\hline energy intake, kcal/kg & $329 \pm 10.09$ & $339 \pm 16.14$ & $329 \pm 5.62$ & $329 \pm 2.44$ & $>0.05$ \\
\hline FCR & $1.88 \pm 0.05$ & $1.98 \pm 0.03$ & $1.89 \pm 0.11$ & $1.90 \pm 0.08$ & $>0.05$ \\
\hline FCE, feed cost/kg egg & $23.54 \pm 0.60$ & $24.10 \pm 0.32$ & $23.19 \pm 1.37$ & $23.60 \pm 0.97$ & $>0.05$ \\
\hline \multicolumn{6}{|l|}{ Weeks 42-49 } \\
\hline egg production, \% & $91.19 \pm 5.01$ & $90.03 \pm 2.98$ & $92.78 \pm 5.36$ & $96.46 \pm 0.57$ & $>0.05$ \\
\hline egg weight, g & $68.31 \pm 0.66$ & $67.81 \pm 1.69$ & $68.54 \pm 1.30$ & $67.47 \pm 2.43$ & $>0.05$ \\
\hline egg mass, g/hen/day & $62.35 \pm 3.08$ & $60.86 \pm 3.75$ & $63.36 \pm 4.04$ & $64.90 \pm 2.13$ & $>0.05$ \\
\hline feed intake, g/hen/day & $116.10 \pm 3.74^{B}$ & $125.83 \pm 3.65^{A}$ & $118.17 \pm 2.41^{\mathrm{B}}$ & $117.84 \pm 2.11^{B}$ & $<0.05$ \\
\hline energy intake, kcal/kg & $326.47 \pm 10.5^{\mathrm{B}}$ & $344.38 \pm 10.00^{A}$ & $323.43 \pm 6.61^{\mathrm{B}}$ & $322.52 \pm 5.79^{B}$ & $<0.01$ \\
\hline FCR & $1.87 \pm 0.13^{\mathrm{B}}$ & $2.07 \pm 0.07^{\mathrm{A}}$ & $1.87 \pm 0.12^{\mathrm{B}}$ & $1.82 \pm 0.04^{B}$ & $<0.05$ \\
\hline FCE, feed cost $/ k g$ egg & $23.43 \pm 1.65^{\mathrm{AB}}$ & $25.18 \pm 0.83^{\mathrm{A}}$ & $22.97 \pm 1.42^{B}$ & $22.53 \pm 0.51^{B}$ & $<0.05$ \\
\hline
\end{tabular}

FCE - feed cost per $1 \mathrm{~kg}$ egg; FCR - feed conversion ratio (feed intake/egg mass); values are express as mean \pm standard deviation (SD); means were obtained from 8 replicates (12 birds each); ${ }^{A B C}$ - means within the same row without the same superscript are significantly different at $P<0.05$ 
Table 4. Effect of lysophosphatidylcholine (LPC) supplementation on blood lipid level and fat digestibility in laying hens

\begin{tabular}{|c|c|c|c|c|c|}
\hline Indices & $\begin{array}{l}\text { Positive Control } \\
\text { (PC) }\end{array}$ & $\begin{array}{l}\text { Negative Control } \\
\text { (NC) }\end{array}$ & $\begin{array}{l}\text { NC+LPC } \\
0.05 \%\end{array}$ & $\begin{array}{l}\text { NC+LPC } \\
0.1 \%\end{array}$ & $P$-value \\
\hline Fat digestibility ${ }^{*} \%$ & $95.29 \pm 0.87^{A}$ & $91.59 \pm 0.79^{B}$ & $95.13 \pm 0.47^{\mathrm{A}}$ & $95.18 \pm 0.68^{A}$ & $<0.01$ \\
\hline Cholesterol $^{* *}, \mathrm{mg} / \mathrm{dl}$ & $86.80 \pm 18.47^{\mathrm{AB}}$ & $57.25 \pm 15.73^{B}$ & $95.43 \pm 31.39^{A}$ & $100.68 \pm 29.45^{A}$ & $<0.05$ \\
\hline Triglyceride ${ }^{* *}, \mathrm{mg} / \mathrm{dl}$ & $521.80 \pm 101.92^{\mathrm{AB}}$ & $424.00 \pm 132.69^{B}$ & $642.30 \pm 158.55^{\mathrm{A}}$ & $654.78 \pm 128.11^{\mathrm{A}}$ & $<0.05$ \\
\hline LDL-C** ${ }^{* *} \mathrm{mg} / \mathrm{dl}$ & $18.80 \pm 4.78^{\mathrm{AB}}$ & $14.67 \pm 4.48^{\mathrm{B}}$ & $26.00 \pm 6.36^{\mathrm{A}}$ & $25.33 \pm 7.94^{\mathrm{A}}$ & $<0.01$ \\
\hline $\mathrm{HDL}-\mathrm{C}^{* *}, \mathrm{mg} / \mathrm{dl}$ & $36.00 \pm 4.80$ & $37.75 \pm 4.03$ & $40.58 \pm 5.74$ & $38.17 \pm 14.47$ & $>0.05$ \\
\hline
\end{tabular}

LDL-C - low-density lipoprotein cholesterol; HDL-C - high-density lipoprotein cholesterol; the values are expressed as mean \pm standard deviation (SD); * - calculated from 8 hens/treatment group; ${ }^{* *}$ - calculated from 8 replicates ( 4 hens per replicate)/treatment group; ${ }^{A B C}-$ means within the same row without the same superscript are significantly different at $P<0.05$

significantly increased triglyceride, cholesterol, and LDL-C in the blood in compariosn to the NC group $(P<0.05)$.

It is known that the supplementation of LPC to the low-energy diet increased the digestibility of dietary fat. Accordingly, Zhao et al. (2015) found that weaning pigs fed a restricted energy diet with the inclusion of LPC at the level of $0.05 \%$ had greater digestibility of fat. In broiler chickens, high digestibility of dietary fat and fatty acids as a result of LPC supplementation was also reported (Han et al., 2010a; Jansen et al., 2015; Allahyari-Bake and Jahanian, 2017). Since LPC has more hydrophilic property than regular phospholipids and bile acid (Langmuir, 2002; Joshi et al., 2006; Liu et al., 2011), supplementing of LPC would increase the emulsification and digestibility of fat. Another reason is that LPC is a part of the phospholipid bilayers and acts as an important regulator in modifying fluidity, it would also improve permeability of the lipid bilayer (Shumilina et al., 2006). Therefore, the increment of fat digestibility and blood lipids content in this study confirms the increase in fat emulsification and/or modification of the lipid bilayer of the enterocyte of laying hens.

Gene expression. Effects of LPC supplementation into diet on the expression of genes related to nutrients transport in the small intestine at 49 weeks of age are presented on Figures 1,2 and 3 . The expression of gene related to the $\mathrm{Na}+$-independent cationic and zwitterionic amino acid transporter $(B A T)$ was significantly increased in the $\mathrm{NC}$ group $(P<0.05)$, while supplemental LPC downregulated the expression of this gene to the values observed for the PC group. Conversely, CAT-1 expression in the NC-LPC $0.1 \%$ group was significantly higher than that in the PC group $(P<0.05)$. The expression of the NPC1 gene (Niemann-Pick $\mathrm{C} 1$ /intracellular cholesterol transporter 1) that is involved in the cholesterol uptake was significantly higher in the NC-LPC 0.05 and $0.1 \%$ groups in comparison to the NC group $(P<0.05)$.

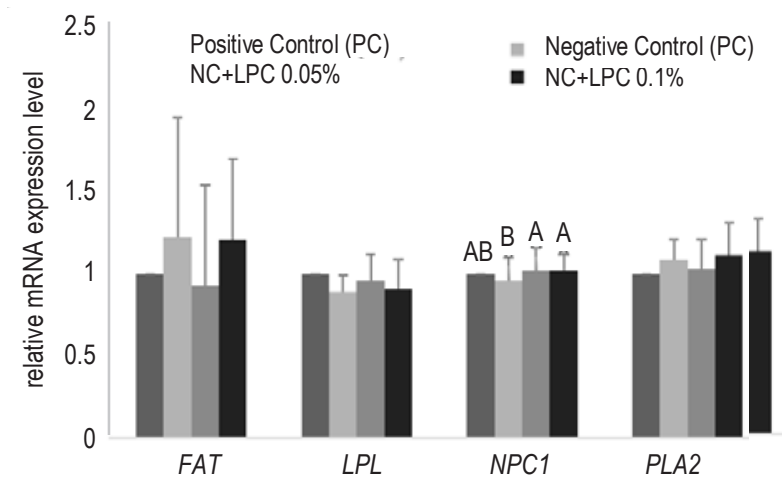

Figure 1. Expression of genes related to fat transport in jejunum: FAT, $L P L, N P C 1, P L A 2$. Bars present means \pm standard deviation (SD), bars with different superscripts are significantly different at $P<0.05$

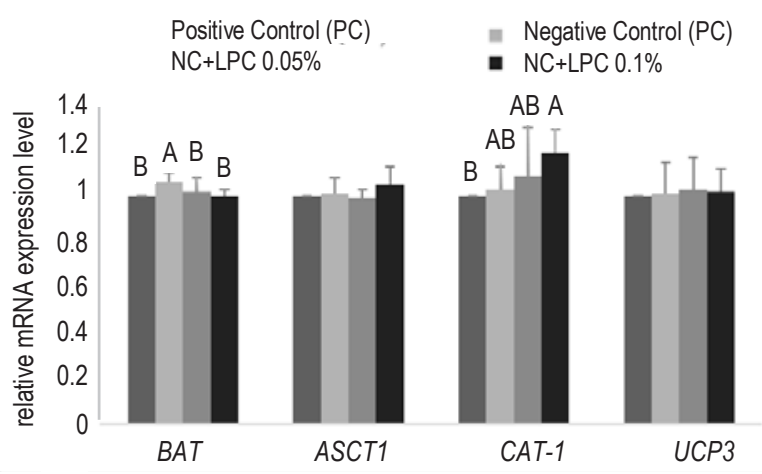

Figure 2. Expression of genes related to amino acids transport in jejunum: BAT, ASCT1, CAT-1 and UCP3. Bars present means \pm standard deviation (SD), bars with different superscripts are significantly different at $P<0.05$

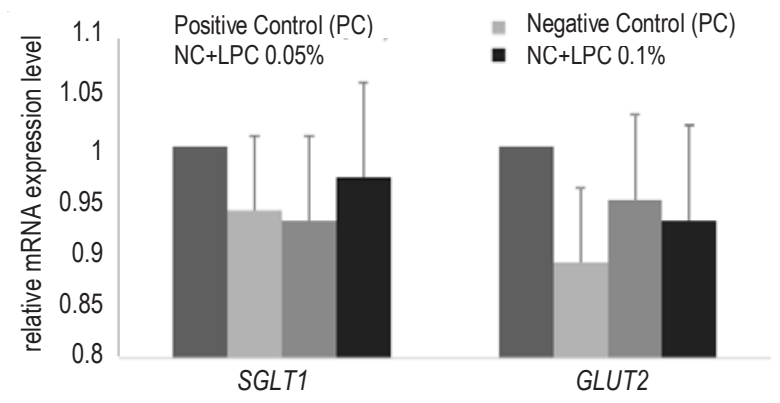

Figure 3. Expression of genes related to glucose transport in jejunum: SGLT1 and GLUT2. Bars present means \pm standard deviation (SD) 
Although gene expression processes are genetically preprogramed, dietary nutrients can activate these processes (Liao et al., 2015; Zhou et al., 2018). The regulation of nutrient transporters in the small intestine is connected with the nutrients present in the diet (Gilbert et al., 2008). Amino acids are transported by neutral, acidic or basic amino acids transporters (Wu, 2013). The BAT gene is encoding the major apical neutral amino acid transporter in the kidney and the small intestine (Bröer, 2008). Although system BAT has broad substrate specificity, the branched chain (leucine, isoleucine) and benzenoid amino acids (tryptophan and phenylalanine) are also preferred (Van Winkle et al., 2006). A reduction of dietary energy content significantly increased the expression of the $B A T$ gene. This may be due to the adaptive regulation linking substrate availability to amino acid transport (Gazzola et al., 1972). Hatzoglou et al. (2004) illustrated the increased transport activity in cells exposed to limited substrate, called adaptive depression. Branched chain amino acids (BCAAs) are essential amino acids, and also regulate many key signalling pathways (Zhang et al., 2017), including secretion of insulin (Nair and Short, 2005), fat metabolism, glucose metabolism, glucose transportation, intestinal barrier function and absorption (Zhang et al., 2017). Therefore, the decrease of energy in the diet may enhance the expression of the BAT to compensate the energy requirementation, while supplementation of LPC to a low-energy diet down-regulates this gene expression due to the increasing fat utilization.

CAT-1 is the major system $y+$ transporter in most cells (system $\mathrm{y}^{+}$, namely its ability to recognize cationic amino acids; lysine and arginine), so it supports the important metabolic functions such as synthesis of proteins, nitric oxide (NO), polyamine and interorgan amino acid flow (Hatzoglou et al., 2004). Lysine is the second limiting amino acid in poultry, and it is generally known that lysine improves productive performance in hens. Different dietary standardised ileal digestible Lys levels affecting the mRNA level of CAT1 in jejunum in weaned pig have been reported (García-Villalobos et al., 2012; Wang et al., 2012). Therefore, it may be hypothesized that the increase of CAT-1 gene expression may increase the lysine uptake to promote egg performance by LPC supplementation, since this improvement has to be supported by both dietary energy and amino acids.

Niemann-Pick C1-Like 1 (NPC1) is localized in the apical membrane of the small intestine absorptive enterocytes that is essential for intestinal sterol absorption (Betters et al., 2010). Thus, NPC1 plays an essential role in the intestinal cholesterol absorption (Altmann et al., 2004). Cholesterol is precursor of sterol hormone, so high level cholesterol is needed by hen to accumulate in the egg, and also for proper function of the hypothalamo-pituitary-ovarian axis and whole reproductive system. Lack of NPC1 reduces weight gain in animals fed a diabetogenic diet (Eric et al., 2008). In the present study, therefore, it is not surprising that the increase in blood cholesterol is paralleled by an increase in the expression of the NPC1 gene. Accordingly, the fat digestibility of laying hens fed low-energy diet supplemented with LPC was improved. This indicates that LPC not only increases the emulsification of fat (increased fat digestibility), but also increases the uptake of cholesterol from the small intestine via the enhancement of the NPCl gene expression. Consequently, the FCR and FCE in hens fed LPC-supplemented diets were better than in those from $\mathrm{PC}$ and $\mathrm{NC}$ groups.

\section{Conclusions}

Supplementing lysophosphatidylcholine (LPC) at the levels of 0.05 and $0.1 \%$ into a low-energy diet improves feed conversion ratio and feed cost per $1 \mathrm{~kg}$ egg in laying hens due to the increment of fat digestibility and absorption. Furthermore, LPC also up-regulates the expression of CAT-1 and $N P C 1$ genes to increase the uptake of some amino acids and cholesterol into the enterocyte.

\section{Acknowledgements}

This research was supported from the Graduate Program Scholarship from the Graduate School, Kasetsart University. The author gratefully acknowledges funding from Easy bio (South Korea) Technology Company.

\section{References}

Allahyari-Bake S., Jahanian R., 2017. Effects of dietary fat source and supplemental lysophosphatidylcholine on performance, immune responses, and ileal nutrient digestibility in broilers fed corn/soybean meal or corn/wheat/soybean meal-based diets. Poult. Sci. 96, 1149-1158, https://doi.org/10.3382/ps/ pew330

Altmann S.W., Davis H.R., Zhu L.J. et al., 2004. Niemann-Pick C1 Like 1 protein is critical for intestinal cholesterol absorption. Science 303, 1201-1204, https://doi.org/10.1126/science.1093131 
AOAC International, 2000. Official Methods of Analysis of AOAC International. 17 $7^{\text {th }}$ Edition. Gaithersburg, MD (USA)

Attia Y.A., Hussein A.S., Tag El-Din A.E., Qota E.M., Abed El-Ghany A.I., El-Sudany A.M., 2009. Improving productive and reproductive performance of dual-purpose crossbred hens in the tropics by lecithin supplementation. Trop. Anim. Health Prod. 41, 461475, https://doi.org/10.1007/s11250-008-9209-3

Baskaran V., Sugawara T., Nagao A., 2003. Phospholipids affect the intestinal absorption of carotenoids in mice. Lipids 38, 705-711, https://doi.org/10.1007/s11745-003-1118-5

Beemster P., Groenen P., Steegers-Theunissen R., 2002. Involvement of inositol in reproduction. Nutr. Rev. 60, 80-87, https://doi. org/10.1301/00296640260042748

Betters J.L., Yu L., 2010. NPC1L1 and cholesterol transport. FEBS Lett. 584, 2740-2747, https://doi.org/10.1016/j.febslet.2010.03.030

Boontiam W., Jung B., Kim Y.Y., 2017. Effects of lysophospholipid supplementation to lower nutrient diets on growth performance, intestinal morphology, and blood metabolites in broiler chickens. J. Poult. Sci. 96, 593-601, https://doi.org/10.3382/ps/pew269

Bröer S., 2008. Amino acid transport across mammalian intestinal and renal epithelia. Physiol. Rev. 88, 249-286, https://doi. org/10.1152/physrev.00018.2006

Eric D., Labonté Lisa M., Camarota J. et al., 2008. Reduced absorption of saturated fatty acids and resistance to diet-induced obesity and diabetes by ezetimibe-treated and Npc111-/- mice. Am. J. Physiol. Gastrointest. Liver Physiol. 295, 776-783, https://doi. org/10.1152/ajpgi.90275.2008

García-Villalobos H., Morales-Trejo A., Araiza-Piña B.A., Htoo J.K., Cervantes-Ramírez M., 2012. Effects of dietary protein and amino acid levels on the expression of selected cationic amino acid transporters and serum amino acid concentration in growing pigs. Arch. Anim. Nutr. 66, 257-270, https://doi.org/10. 1080/1745039X.2012.697351

Gazzola G.C., Franchi R., Saibene V., Ronchi P., Guidotti G.G., 1972. Regulation of amino acid transport in chick embryo heart cells. I. Adaptive system of mediation for neutral amino acids. Biochim. Biophys. Acta 266, 407-421, https://doi.org/10.1016/00052736(72)90097-1

Gilbert E.R. , Li H., Emmerson D.A., Webb K.E. Jr, Wong E.A., 2007. Developmental regulation of nutrient transporter and enzyme mRNA in the small intestine of broiler chicks. Poult. Sci. 86, 1739-1753, https://doi.org/10.1093/ps/86.8.1739

Gilbert E.R., Li H., Emmerson D.A., Webb K.E., Wong E.A., 2008. Dietary protein quality and feed restriction influence abundance of nutrient transporter mRNA in the small intestine of broiler chicks. J. Nutr. 138, 262-271, https://doi.org/10.1093/ $\mathrm{jn} / 138.2 .262$

Han Y.K., Jin Y.H., Kim J.H., Thacker P.A., 2010a. Influence of enzyme and/or lysolecithin supplementation on performance, nutrient digestibility and egg quality for laying hens. Trends Anim. Vet. Sci. J. 1, 28-35

Han Y.K., Jin Y.H., Lee W.I., Lee K.T., Thacker P.A., 2010b. Influence of Lysolecithin on the performance of laying hens, interior and exterior egg quality as well as fat soluble vitamin and cholesterol content in the yolk. J. Anim. Vet. Adv. 9, 2583-2588, https://doi. org/10.1146/annurev.nutr.23.011702.073120

Hatzoglou M., Fernandez J., Yaman I., Closs E., 2004. Regulation of cationic amino acid transport: the story of the CAT-1 transporter. Annu. Rev. Nutr. 24, 377-399, https://doi.org/10.1146/annurev. nutr.23.011702.073120

Jansen M., Nuyens F., Buyse J., Leleu S., Van Campenhout L., 2015. Interaction between fat type and lysolecithin supplementation in broiler feeds. Poult. Sci. 94, 2506-2515, https://doi.org/10.3382/ ps/pev181
Joshi A., Paratkar S.G., Thorat B.N., 2006. Modification of lecithin by physical, chemical and enzymatic methods. Eur. J. Lipid Sci. Technol. 108, 363-373, https://doi.org/10.1002/ejt.200600016

Kelkar D.A., Chattopadhyay A., 2007. The gramicidin ion channel: A model membrane protein. Biochim. Biophys. Acta 1768, 2011-2025, https://doi.org/10.1016/j.bbamem.2007.05.011

Khan M.A., Mahr-un-Nisa, Sarwar M., 2003. Techniques measuring digestibility for the nutritional evaluation of feeds. Inter. J. Agric. Biol. 5, 91-94

Langmuir L.T., 2002. Lecithin: In: A.T. Hubbard (Editor). Encyclopedia of Surface and Colloid Science. Marcel Dekker Inc., New York, NY (USA)

Liao S.F., Wang T., Regmi N., 2015. Lysine nutrition in swine and the related monogastric animals: muscle protein biosynthesis and beyond. Springerplus 4, 147, https://doi.org/10.1186/s40064015-0927-5

Liu D., Ma F., 2011. Soybean phospholipids. In: D. Krezhova (Editor). Recent Trends for Enhancing the Diversity and Quality of Soybean Products. IntechOpen. Rijeka (Croatia), pp. 483-500, https://doi.org/10.5772/1005

Livak K.J., Schmittgen T.D., 2001. Analysis of relative gene expression data using real-time quantitative PCR and the $2^{-\Delta \Delta C T}$ method. Methods 25, 402-408, https://doi.org/10.1006/meth.2001.1262

Lundbaek J.A. Collingwood S.A., Ingólfsson H.I., Kapoor R., Andersen O.S., 2010. Lipid bilayer regulation of membrane protein function: gramicidin channels as molecular force probes. J. R. Soc. Interface. 7, 373-395

Maingret F., Patel A.J., Lesage F., Lazdunski M., Honoré E., 2000. Lysophospholipids open the two-pore domain mechanogated $\mathrm{K}(+)$ channels TREK-1 and TRAAK. J. Biol. Chem. 275, 10128-10133, https://doi.org/10.1074/jbc.275.14.10128

Malapure C.D., Kawitkar S.B., Deshmukh G.B., Bendale L.N., Patankar R.B., 2011. Influence of dietary supplementation of phospholipids and lysophospholipids on performance of broilers. Indian J. Anim. Nutr. 28, 316-319

Mandalawi H.A., Lázaro R., Redón M., Herrera J., Menoyo D., Mateos G.G., 2015. Glycerin and lecithin inclusion in diets for brown egg-laying hens: Effects on egg production and nutrient digestibility. Anim. Feed Sci. Technol. 209, 145-156, https:// doi.org/10.1016/j.anifeedsci.2015.07.019

Nair K.S., Short K.R., 2005. Hormonal and signaling role of branchedchain amino acids. J. Nutr. 135, 1547-1552, https://doi. org/10.1093/jn/135.6.1547S

Saneyasu T., Kimura S., Kitashiro A., Tsuchii N., Tsuchihashi T., Inui M., Honda K., Kamisoyama H., 2015. Differential regulation of the expression of lipid metabolism-related genes with skeletal muscle type in growing chickens. Comp. Biochem. Physiol. B Biochem. Mol. Biol. 189, 1-5, https://doi.org/10.1016/j. cbpb.2015.07.002

SAS (Statistical Analysis System), 2014. The SAS System version 9.4. SAS Institute, Inc., Cary, NC (USA)

Shumilina E.V., Khromova Y.L., Shchipunov Y.A., 2006. The effect of lysophosphatidylcholine and phosphatidylglycerol on lecithin polymer-like micelles. Colloid J. 68, 241-247, https://doi. org/10.1134/S1061933X06020177

Van Winkle L.J., Tesch J.K., Shah A., Campione A.L, 2006. System $\mathrm{B} 0,+$ amino acid transport regulates the penetration stage of blastocyst . implantation with possible long-term developmental consequences through adulthood. Hum. Reprod. Update 12, 145-157, https://doi.org/10.1093/humupd/dmi044

Vasanthakumari B.L., Chandrakekar K.V., Ravindran V., 2011. How lysophospholipid improve the apparent metabolizable energy (AME) in broiler diets, http://www.efeedlink.com/contents/0407-2011/3d1d6cd9-cf44-466c-8ec9-d6f1dfab6ecc 
Wang X.Q., Zeng P.L., Feng Y., Zhang C.M., Yang J.P., Shu G., Jiang Q.Y., 2012. Effects of dietary lysine levels on apparent nutrient digestibility and cationic amino acid transporter mRNA abundance in the small intestine of finishing pigs, Sus scrofa. Anim. Sci. J. 83, 148-155, https://doi.org/10.1111/j.17400929.2011.00941.x

Wu G. (Editor), 2013. Amino Acids: Biochemistry and Nutrition. CRC Press. Boca Raton, FL (USA)

Xing J.J., Heugten E.V., Lit K.J., Touchetter D.F., Coalson J.A., Odgaard R.L., Odle J., 2004. Effects of emulsification, fat encapsulation and pelleting on weanling pig performance and nutrient digestibility. J. Anim. Sci. 82, 2601-2609, https://doi. org/10.2527/2004.8292601x

Zhang B., Haitao L., Zhao D., Guo Y., Barri A., 2011. Effect of fat type and lysophosphatidylcholine addition to broiler diets on performance, apparent digestibility of fatty acids, and apparent metabolizable energy content. Anim. Feed Sci. Technol. 163, 177-184, https://doi.org/10.1016/j.anifeedsci.2010.10.004
Zhang S., Zeng X., Ren M., Mao X., Qiao S., 2017. Novel metabolic and physiological functions of branched chain amino acids: a review. J. Anim. Sci. Biotechnol. 8, 10-22, https://doi. org/10.1186/s40104-016-0139-z

Zhao P.Y., Li H.L., Hossain M.M., Kim I.H., 2015. Effect of emulsifier (lysophospholipids) on growth performance, nutrient digestibility and blood profile in weanling pigs. Anim. Feed Sci. Technol. 207, 190-195, https://doi.org/10.1016/j.anifeedsci.2015.06.007

Zhou H., Chen D.W., Mao X.B., He J., Yu J., Zheng P., Luo J.Q., Gao J., Htoo J., Yu B., 2018. Effects of dietary lysine levels on jejunal expression of amino acids transporters and hindgut microflora in weaned pigs. J. Anim. Feed Sci. 27, 238-247, https://doi.org/10.22358/jafs/93736/2018 